\title{
ГЕМОДИНАМІЧНІ ЗМІНИ У ЖІНОК 3 ХРОНІЧНИМИ ЗАПАЛЬНИМИ ЗАХВОРЮВАННЯМИ ПРИДАТКІВ МАТКИ
}

\author{
Кафедра акушерства та гінекології 1 (зав. - проф. М. О. Шербина) \\ Харківського національного медичного університету <kapustnik.valerij@ukr.net>
}

\begin{abstract}
Вивчено особливості гемодинаміки органів малого таза, реологічних властивостей крові та маркеру ендотеліальної дисфункиї у 30 жінок з хронічними запальними захворюваннями придатків матки (основна група). Контрольну групу становили 30 здорових жінок репродуктивного віку. Встановлено, що значну роль у розвитку хронічних запальних захворювань придатків матки відіграють гемодинамічні та реологічні порушення.
\end{abstract}

Ключові слова: запальні захворювання придатків матки; допплерометрія; ендотелін-1; реологічні властивості крові.

Запальні процеси в статевих органах домінують серед гінекологічних захворювань у пацієнток репродуктивного віку, негативно впливаючи на їх менструальну та репродуктивну функції, які призводять до зниження працездатності та значних економічних втрат, пов'язаних з діагностикою і лікуванням [2, 5]. На сучасному етапі питома вага запальних захворювань придатків матки в структурі гінекологічної патології становить від 55 до 95 \% [4, 10]. У 24-96 \% хворих із запальними захворюваннями придатків матки (З3ПМ) спостерігаються порушення регіонарної та периферичної гемодинаміки [3]. Відмічаються такі порушення системи кровопостачання органів малого тазу: зменшення еластичності артерій і артеріол, поява ознак гіпотонії та ускладненого відтоку крові з артеріального відділу у вени, зниження кровонаповнення. В основі уповільненого кровообігу і застійних явищ у малому тазі лежать анатомічні зміни вен, склеротичні процеси в судинах мікроциркуляторного русла, розростання сполучної тканини, атеросклероз і варикозне розширення венул [6, 9]. Порушення регіонарної гемодинаміки погіршує трофіку тканин, спричинює появу тривало існуючих зон анемізації або венозного повнокров'я в органах малого таза, розвиток і підтримку запальних та дистрофічних змін в провідниковому і рецепторному апараті придатків матки, тим самим провокуючи больовий синдром [1, 7]. Незважаючи на велику кількість досліджень, ця проблема дотепер не вирішена та потребує подальшого вивчення.

Мета дослідження - визначити особливості гемодинаміки органів малого таза, реологічних властивостей крові та маркера ендотеліальної дисфункції у жінок 3 хронічними З3ПМ.

Матеріали і методи. Обстежено 60 жінок у віці від 20 до 40 років, яких розподілено на дві клінічні групи. До I (контрольної) групи $(n=30)$ увійшли практично здорові жінки, у яких не виявлено З3ПМ; до II (основної) групи $(n=30)-$ пацієнтки з хронічними ЗЗПМ.

Допплерометричне дослідження здійснювали шляхом вивчення кривих швидкостей кровообігу в маткових і яєчникових артеріях в ділянці бічних стінок малого таза за загальноприйнятою методикою.

Властивості реології крові оцінювали шляхом визначення в'язкості крові і рівня гематокриту. В'язкість визначали за допомогою ротаційного віскозиметра за стандартною шкалою.

Визначення ендотеліну-1 в плазмі крові проводили імуноферментним методом на фотометрі Humareader (Німеччина) за набором реактивів Endothelin-1 ELISA (фірма «Amersham pharmaciabiotech», Велика Британія).

Статистичну обробку отриманих даних проводили з використанням пакетів програм Statistica 7 і Excel 2010 (Microsoft). Порівняння середніх здійснювали за 
двостороннім $t$-критерієм Стьюдента для незалежних змінних. Достовірність відмінностей вважали при $\mathrm{P}<0,05$.

Результати та їх обговорення. Допплерометричне дослідження особливостей кровообігу в яєчникових і маткових артеріях проведено всім пацієнткам у фолікулінову фазу (рис. 1, 2).

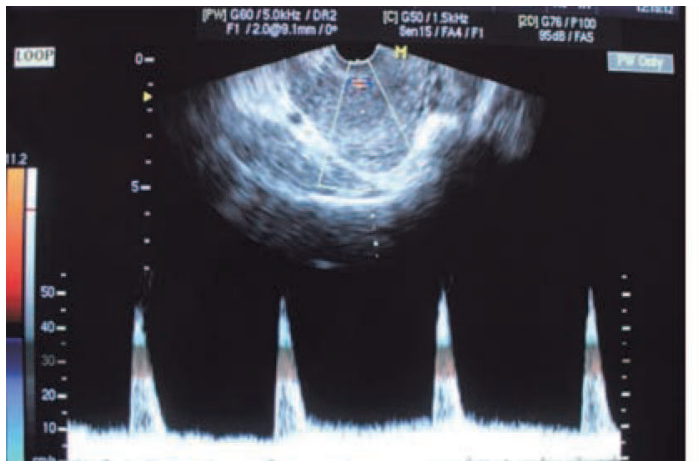

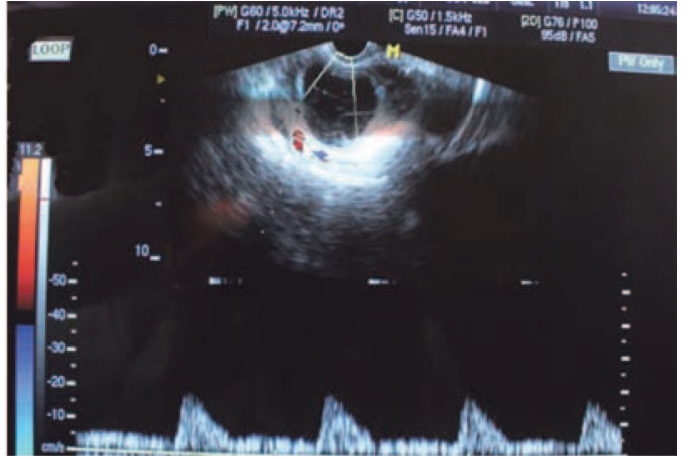

6

Рис. 1. Допплерограма кровообігу в матковій $(a)$ та яєчниковій (б) артеріях хворої І., 23 років (спостереження 23), без хронічних З3ПМ

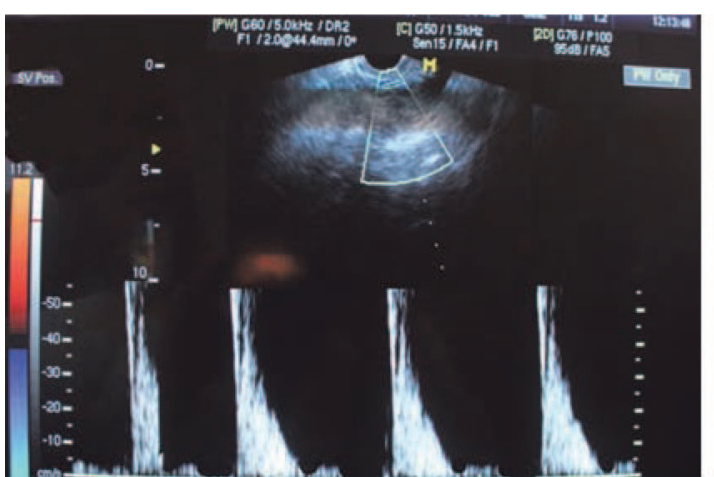

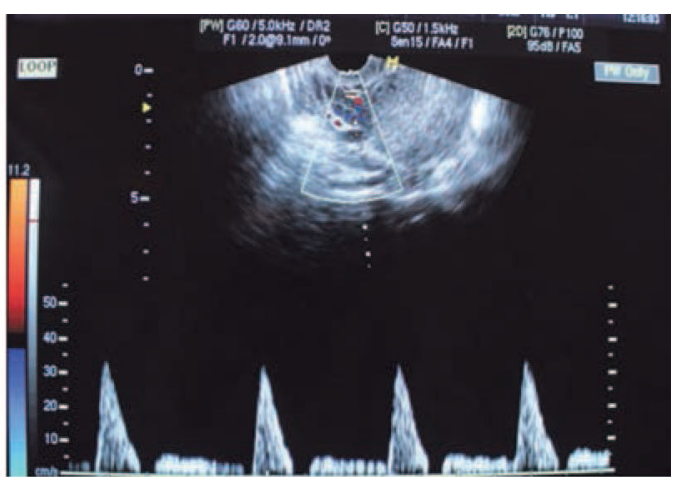

$\sigma$

Рис. 2. Допплерограма кровообігу в матковій $(a)$ та яєчниковій (б) артеріях хворої I., 27 років (спостереження 41), з хронічними З3ПМ

Допплерограма кровообігу в маткових та яєчникових артеріях у жінок контрольної групи мала вигляд двофазної кривої без нульових і негативних компонентів. Аналіз допплерограми маткових і яєчникових артерій показав, що значення індексу судинного опору у жінок з хронічними З3ПМ значно вище, ніж у пацієнток контрольної групи.

При цьому відмічено уповільнення систолічної та діастолічної швидкості кровообігу порівняно із здоровими жінками. Так, у жінок II групи систолічна та діастолічна швидкість кровообігу в матковій артерії становила $(0,37 \pm 0,01) \mathrm{m} / \mathrm{c}$ та $(0,14 \pm 0,02)$ м/с відповідно, що достовірно нижче, ніж у жінок контрольної групи, $-(0,62 \pm 0,02)$ м $/ \mathrm{c} \mathrm{i}(0,24 \pm 0,01)$ м $/ \mathrm{c}(\mathrm{P}<0,05)$. Систоло-діастолічне співвідношення (СДС) у жінок II групи у матковій артерії було вищим і становило 2,64 \pm 0,22 порівняно з жінками контрольної групи $-2,58 \pm 0,11(\mathrm{P}<0,05)$. Систолічна швидкість кровообігу становила в правій яєчниковій артерії $(0,18 \pm 0,02)$ м/с, в лівій - $(0,17 \pm 0,02)$ м/с, що достовірно нижче, ніж у жінок I групи, у яких в правій яєчниковій артерії систолічна швидкість становила $(0,27 \pm 0,02) \mathrm{M} / \mathrm{c}$, в лівій - $(0,25 \pm 0,02)$ м $/$ с $(\mathrm{P}<0,05)$. Діастолічна швидкість кровообігу в правій яєчниковій артерії в II групі становила $(0,22 \pm 0,01)$ м/с, в лівій - $(0,30 \pm 0,01)$ м/с, 
тоді як в I групі - відповідно $(0,65 \pm 0,01)$ м/с та $(1,74 \pm 0,01)$ м $/$ с $(\mathrm{P}<0,05)$. Показники СДС були підвищеними у жінок II групи: в правій яєчниковій артеpiï $-1,91 \pm 0,03$, у лівій $-2,50 \pm 0,02$ порівняно 3 жінками I групи - відповідно $0,41 \pm 0,02$ i $0,14 \pm 0,02(\mathrm{P}<0,05)$.

Пульсаційний індекс (ПІ) у хворих на З3ПМ у матковій артерії значно знижувався і становив $0,91 \pm 0,02$ порівняно з жінками контрольної групи $-3,97 \pm$ $0,01(\mathrm{P}<0,05)$. ПІ в яєчникових артеріях був майже в 2 рази нижчим у жінок II групи (в правій $-0,85 \pm 0,01$, в лівій $-0,81 \pm 0,01$ ) порівняно $з$ жінками I групи (в правій - 1,62 $\pm 0,05$, в лівій $-1,59 \pm 0,05 ;$ Р $<0,05)$.

Індекс резистентності (IP) у матковій артерії у хворих основної групи був у 1,5 раза вищим, ніж у жінок контрольної групи, - відповідно 1,06 \pm 0,01 і 0,61 \pm $0,01(\mathrm{P}<0,05)$. У правій яєчниковій артерії IP у хворих на хронічні З3ПМ досягав $0,67 \pm 0,02$, в лівій $-0,68 \pm 0,01$, що достовірно відрізнялося від контрольної групи: в правій $-0,45 \pm 0,02$, в лівій $-0,40 \pm 0,01(\mathrm{P}<0,05)$.

Високі показники значення IP у хворих на хронічні 3ЗПМ свідчать про підвищення периферичного опору судин і порушення кровообігу в органах малого таза. Допплерограма кровообігу в яєчникових артеріях мала вигляд однофазної кривої із систолічним піком, діастолічний пік практично відсутній, що вказує на ї високу резистентність.

Необхідно відзначити, що у жінок з хронічними З3ПМ показники судинного опору були постійно високими, що свідчить про низьку швидкість кровообігу в яєчникових і маткових судинах.

У 27 (90 \%) пацієнток з хронічними З3ПМ виявлено підвищення показників реологічних властивостей крові: в'язкість - $(17,79 \pm 0,04)$ сПз, гематокритне число - 0,44 \pm 0,36 порівняно з контрольною групою - відповідно $(5,11 \pm 0,09)$ сПз та $0,37 \pm 0,24(\mathrm{P}<0,05)$, що свідчить про гемоконцентрацію, яка також призводить до уповільнення кровообігу й порушень мікроциркуляції.

Для оцінки стану механізмів ендотелійзалежної релаксації визначали вміст ендотеліну-1 у жінок з хронічними З3ПМ, який становив $(13,21 \pm 0,83)$ нг/л, що перевищувало майже вдвічі показники контрольної групи - $(5,8 \pm 0,6)$ нг/мл $(\mathrm{P}<0,05)$. Отримані дані вказують на ендотеліальну дисфункцію у хворих на хронічні ЗЗПМ.

Висновки. Патогенетичну основу розвитку хронічних З3ПМ визначають порушення гемодинамічних параметрів та гемоконцентрація. Таким чином, у хворих відбувається уповільнення кровообігу в маткових і яєчникових артеріях, що свідчить про високу судинну резистентність, яка призводить до стазу крові в органах малого таза та може бути тригером для розвитку ендотеліальної дисфункції, на що вказують зміни показників ендотеліну-1.

$$
\text { С пи с ок л і те рат у ри }
$$

1. Абдульхакім Аль-Сабан, Волянська Н. П., Сидорчук А. Г. Біологічні властивості та чутливість до протимікробних препаратів збудників гнійно-запальних захворювань // Буков. мед. вісн. - 2002. - Т. 6, № 4. - С. 165-167.

2. Вениківський Б. М., Товстановська В. О. Інфекції, що передаються статевим шляхом // Мистецтво лікування. - 2004. № $6 .-$ C. $52-55$.

3. Газазян М. Г., Хардиков А. В., Сухих Н. В. Оптимизация диагностики и лечения хронических сальпингоофоритов // Рос. вестн. акушера-гинеколога. - 2009. № 3. - С. 67-71.

4. Дубоссарская 3. М., Миляновский А. И., Коляденко В. Г. Хронические воспалитель-
1. Abdul'hakim Al'-Saban, Volyans'ka N. P., Sidorchuk A. G. Biologichni vlastivosti ta chutlivist' do protimikrobnih preparativ zbudnikiv gnijno-zapal'nih zahvoryuvan' // Bukov. med. visn. - 2002. - T. 6, № 4. S. $165-167$.

2. Venckivs'kijB.M., Tovstanovs'ka V.O. Infekcii, shcho peredayut'sya statevim shlyahom // Mistectvo likuvannya. - 2004. - № 6. S. 52-55.

3. Gazazyan M. G., Hardikov A. V., Suhih N. V. Optimizaciya diagnostiki i lecheniya hronicheskih sal'pingooforitov // Ros. vestn. akushera-ginekologa. - 2009. - № 3. - S. 67-71.

4. Dubossarskaya Z. M., Milyanovskij A. I., Kolyadenko V. G. Hronicheskie vospali- 
ные процессы внутренних женских половых органов. - К.: Здоровья, 2003. C. $115-118$.

5. Кушнир С. В.Оценка качества жизни больных с хроническими воспалительными заболеваниями придатков матки // Вестн. неотложной и вспомогательной медицины. - 2006. - Т. 7, № 3. - С. 421-423.

6. Козак О. М., Польова С. П., Рогачов I. Є Діагностика та патогенетичне лікування хронічних запальних захворювань геніталій // Зб. наук. праць асоціації акушерівгінекологів України. - К.: Інтермед, 2011. - C. 445-449.

7. Сенчук А. Я., Ропяк А. М., Доскач I. О. Стан системи гемостазу у хворих із хронічним сальпінгоофоритом у стадії загострення до та після протизапальної терапії // Актуальні питання педіатрії, акушерства і гінекології. - 2009. - № 1. - С. 76-78.

8. Хачкурузов С.Г. УЗИ в гинекологии. Симптоматика. Диагностические трудности и ошибки. - СПб: Элби-СПб, 2004. - 661 с

9. Soper D. E. Pelvic inflammatory disease // Obstet. Gynecol. - 2010. - Vol. 116, N 2. - P. 419 429.

\section{ГЕМОДИНАМИЧЕСКИЕ ИЗМЕНЕНИЯ \\ У ЖЕНЩИН С ХРОНИЧЕСКИМИ ВОСПАЛИТЕЛЬНЫМИ ЗАБОЛЕВАНИЯМИ ПРИДАТКОВ МАТКИ}

\section{H. В. Капустник (Харьков)}

Изучены особенности гемодинамики органов малого таза, реологических свойств крови и маркёра эндотелиальной дисфункции у 30 женщин с хроническими воспалительными заболеваниями придатков матки (основная группа). Контрольную группу составили 30 здоровых женщин репродуктивного возраста. Установлено, что значительную роль в развитии хронических воспалительных заболеваний придатков матки играют гемодинамические и реологические нарушения.

Ключевые слова: воспалительные заболевания придатков матки; допплерометрия; эндотелин-1; реологические свойства крови.

\section{HEMODYNAMICCHANGES IN WOMEN WITH INFLAMMATORY DISEASES OF UTERINE APPENDAGES}

\author{
N. V. Kapustnik (Kharkiv, Ukraine) \\ Kharkiv National Medical University
}

The features of pelvic hemodynamics, blood rheology and marker of endothelial dysfunction in 30 women with chronic inflammatory diseases of the uterine appendages (the main group) was studied. The control group consisted of 30 healthy women of reproductive age. It was established that hemodynamic and rheological disfunctions play a significant role in the development of chronic inflammatory diseases of the uterine appendages.

Keywords: inflammatory diseases of the uterine appendages; Doppler; endothelin-1; the rheological properties of blood. 